\title{
"I have no pleasure in collecting for myself alone": 1 Social Authorship, Networks of Knowledge and Etheldred Benett's Catalogue of the Organic Remains of the County of Wiltshire (1831)
}

\section{Susan Pickford}

As with many other fields of scientific endeavour, the relationship between literature and geology has proved a fruitful arena for research in recent years. Much of this research has focused on the founding decades of the earth sciences in the early- to mid-nineteenth century, with recent articles by Gowan Dawson and Laurence Talairach-Vielmas joining works such as Noah Heringman's Romantic Rocks, Aesthetic Geology (2003), Ralph O'Connor's The Earth on Show: Fossils and the Poetics of Popular Science, 1802-1856 (2007), Virginia Zimmerman's Excavating Victorians (2008) and Adelene Buckland's Novel Science: Fiction and the Invention of Nineteenth-Century Geology (2013), to explore the rhetorical and narrative strategies of writings in the early earth sciences. It has long been noted that the most institutionally influential early geologists formed a cohort of eager young men who, having no tangible interests in the economic and practical applications of their chosen field, were in a position to develop a passionately Romantic engagement with nature, espousing an apocalyptic rhetoric of catastrophes past and borrowing epic imagery from Milton and Dante (Buckland 9, 14-15). However, as Buckland further notes, this argument - though persuasive as far as it goes - fails to take into account the broad social range of participants in the construction of early geological knowledge. The aim of this article, then, is to address the publishing strategies of one such participant excluded from the formal geological institutions of the nineteenth century, the early British geologist Etheldred Benett (1776-1845), drawing on Ann B. Shteir's valuable work in recovering the "literary history of women's science writing" (Shteir, "Finding Phebe"), and combining the insights it affords us with Margaret Ezell's concept of social authorship, which questions the assumption that getting into print and enjoying a wide circulation was the ambition of all writers. Ezell's work focuses on the ongoing circulation of manuscript material in the late seventeenth and early eighteenth centuries, arguing convincingly that "the geographic situation of the author or the nature of the anticipated audience" are significant factors in determining "the author's choice of "publication' practices" (4). As she makes clear:

Our literary histories have tended to suggest that the only reasons for not embracing print were psychological and social inhibitions. Factors such as the writer's gender or class or combination of the two are prominently discussed as barriers to full participation in the new technology, in the new experience of authorship. Such psychologically based historical analysis of authorship [...] often overlooks or devalues the advantages of the older model of being an author - script texts and a controlled readership - in particular for women writers but also for any writer living outside London. (103-04)

The present article seeks to apply Ezell's model to an early-nineteenth-century context, positing that privately printed and distributed material is the nineteenth- 
century equivalent of privately circulated manuscripts, the lower cost and widespread availability of print technology making it a viable, indeed more practical, alternative to manuscript for works intended for limited circulation. It presents a case study of Etheldred Benett, now hailed as "the first lady geologist" (see: Burek), as a "social author" whose venture into print was determined by her geographical location and the nature of her audience as well as her gender. In particular, the article focuses on the conditions in which Benett published her Catalogue of the Organic Remains of the County of Wiltshire in 1831, exploring the extent to which they both reflected and determined the gender-based marginalisation of its author in nineteenth-century geological circles, studying the publishing strategies she used to contribute to formal geological discourse from within the informal network of knowledge exchange to which her gender restricted her.

\section{The construction of modern geological science in the early nineteenth century}

It was in the following terms that Sir Roderick Murchison highlighted the importance of networks of knowledge exchange in the formation of modern geological science in his presidential address to the Geological Society of London in 1832:

Few indeed are the memoirs which have been completed without the aid of other distinguished Fellows of the Society, who, each in the branch of natural knowledge for which he stands pre-eminent, comes to the assistance of his wandering associate [...] For where is the working geologist who, unassisted, can unravel the delicate and obscure complications of fossil organic structure? [...] Surely every contributor to our Transactions will acknowledge with gratitude the aid he may have received from several of our most gifted members, who, unambitious of personal fame, have been contented with the delightful consciousness of being sure, though silent instruments, in urging on the advance of truth. (Murchison 385-86)

The Romantic vision of the scientist as solitary genius has been largely deconstructed by recent work in the history and sociology of science (Topham 22): much research now highlights the importance of social networks in developing modern scientific culture and thought, not only through formal institutions, but also informal groupings such as the artisan botanists who met in Lancashire pubs (see: Secord). Geology represents an interesting arena in which to investigate such networks, as it was very much an emergent field of scientific endeavour in the late eighteenth and early nineteenth centuries: the first specialist journal, the Journal for Amateurs of Mineralogy and Conchology [Journal für die Liebhaber des Steinreichs und der Konchyliologie], was published in Weimar in 1773 (Meadows 2) and there was a considerable upswing in earth science titles between 1801 and the 1860s (Topham 10). At this early stage in its institutionalisation, geology attracted a broad range of participants. Many practitioners came to it as an applied science from professional backgrounds in mining, quarrying and surveying, while others approached it as a gentlemanly "vocational" science that allowed them to indulge a taste for theorising (Porter 810). It also attracted collectors and proved popular with women, as Charles Wilton noted in 1828: "Every lady has her Outlines of Geology - her bag and her hammer; and no drawing room is considered complete in its furniture, which has not its little cabinet and museum" (qtd. in Turner et al. 113). As a field-based science, it allowed for amateur participation for longer than laboratory-based disciplines 
(O'Connor and Meadows 78), so that as late as 1907, W. B. Woodward was writing: "It is one of the advantages of geology that it is a truly recreative science [...] It is a satisfaction to know that attractive and important work can now and ever be done, as of old, by those who [...] had no academic training" (O'Connor and Meadows 79).

Participants in the construction of geological knowledge thus ranged across the social scale. As well as eminent scientists such as Charles Lyell, Gideon Mantell and Sir Roderick Murchison, they included working quarrymen like George Warren, credited by Benett with finding fossils for her collection in her 1816 manuscript on Alcyonia (Torrens et al. 89), and collectors from relatively modest backgrounds such as Robert Dick, a Thurso baker (Woodward 222), and Mrs. Gent, wife of a Devizes brewer (Haycock 4). The Geological Society's founding manifesto envisioned the knowledge network in the field as one encompassing "the Miner, the Quarrier, the Surveyor, the Engineer, the Collier, the Iron Master and even the Traveller" as well as the "Philosophers" at the Society (Buckland 6). However, this idealistic vision of intellectual partnership was belied by the way access to the institutions of geological knowledge was restricted in terms of class, gender and geography. As the silk weaver Joseph Gutteridge complained in his autobiographical Light and Shadows in the Life of an Artisan, "[a] working man is, by force of circumstances, precluded from studying geology in a scientific manner. To study the science properly, a man must have time and means at his command, and education as well as a natural inclination" (qtd. in Woodward 249). Women were similarly discouraged from playing a full part in geological life on the grounds that field work involved visits to "spots the most lonely and desert [sic] [...] pits and quarries, to railway-cuttings or mines, where none but men - and not always polite men - are at work" (Woodward 265). Provinciality was a further discriminator: as the geologist Robert Bakewell, believed to have been born to a Quaker family in the Nottinghamshire wool trade, noted in 1830: "there is a certain prejudice more or less prevalent among the members of scientific societies in large cities, [...] which makes them unwilling to believe that persons residing in provincial towns or in the country can do anything important for science; and it is strangely imagined that a city geologist, who runs over a district in a few days, can make greater discoveries than anyone residing in it" (qtd. in Knell 41). Consequently, the various networks of knowledge exchange spanning the field of geology had varying degrees of agency as arbiters of scientific legitimacy, determined largely by their access to the formal institutional bodies that soon sought to structure the field, which in turn depended largely on the social capital of individual practitioners.

The Geological Society, founded in 1807 , offers an interesting case study in how formal and informal networks overlapped and interacted in constructing the modern scientific field. It was one of a plethora of scholarly scientific societies to spring up in the early decades of the nineteenth century. While the bulk of these represented a "tangle of minor bodies [for] the large under-class of the scientifically inclined" (Allen 247), the Society catered solely for wealthy collectors with an amateur interest in geology. Its membership was typified by its founding president, London-born, Eton-educated George Bellas Greenough (1778-1855), heir to a patent medicine fortune. The Society was originally set up as "a little talking Geological Dinner Club" for the informal exchange of geological knowledge: a resolution passed at its first meeting stated its purpose as "making geologists acquainted with each other" (see: "History of the Geological Society"). The inaugural dinner cost fifteen shillings (Lewis and Knell 74, 439). New members were vouched for by existing ones and the calendar of events at the society's premises in Somerset House was dictated 
by the London social season, while members from the provinces would treat the society as a gentleman's club when in town (Rudwick, The Great Devonian Conspiracy 22-24). As a result, geological authority was highly concentrated in spatial terms, occupying a handful of streets in central London that were home to both the major institutions and to leading geologists (The Great Devonian Conspiracy 35).

While the Society was initially planned as an informal exchange, its membership expanded rapidly to reach 341 by 1815 , making the informality of its early meetings impractical. Its membership, drawn from the social and scientific elite, soon sought to elevate it to the status of a formal institution. It received a royal patent in 1825, making it the principal arbiter of geological authority in Britain, despite the de facto exclusion of professional geological practitioners of equal expertise but of humbler social origin, such as William Smith, the Oxfordshire-born son of a blacksmith who compiled the first geological map of Britain. As such, the society constituted a "self-sustaining, self-validating knowledge elite" (Porter 810). Perhaps understandably, this led to hostility towards the society from geologists excluded on social grounds. William Smith declared himself suspicious of its members, considering them "pilferers of information" who "considered all unpublished observations as lawful plunder" (Knell 14). Smith's nephew John Phillips, later Professor of Geology at Oxford University, memorably described them as "a band of busy, jealous, active and revengeful witlings [who] have gained and kept their ascendancy partly from contempt, partly from the indolence of others" (Knell 31).

\section{Publishing the Catalogue of the Organic Remains of the County of Wiltshire}

Etheldred Benett represents an interesting opportunity to study how geology drew on a broad social range of practitioners in informal networks of knowledge exchange, while excluding them from its formal institutions. Born into the Wiltshire landed gentry in 1776, she never married, which left her time to foster an interest in the fossils that abounded in the local fields. Her interest in geology was initially sparked by her brother-in-law, the botanist Aylmer Bourke Lambert, himself a founder member of the Linnean Society and member of the Geological Society. Benett was well placed to develop her hobby, as Wiltshire "features right at the dawn of scientific geology" (Delair 132). William Smith's observations on the natural position of chalk formations were based largely on observations made in the vicinity of Warminster, while his pupil Joseph Townsend, a familiar local figure thanks to his work as county commissioner of turnpike roads, made it a fashionable hobby (Delair 136-37). Benett was thus part of an informal local geological culture that dated from the late eighteenth century: she welcomed visitors to her collection from as early as 1809 , when William Cunnington's daughter noted that "Papa and Mama went to see Miss Benett's collection" (Torrens et al. 62).

The significance of this unofficial local network should not be underplayed in terms of encouraging Benett's ongoing interest in geology. However, ill health and family troubles posed a constant challenge to her attempts to keep abreast of developments in the field, as she wrote ruefully to Gideon Mantell: "for the last four or five years circumstances have arisen so fast one upon the other to occupy my time and attention against my wishes and against my will that all my own pursuits and pleasures have been obliged to yield to it [...] I must not lose sight of the few opportunities now afforded me of gaining geological information for I feel that I am very much behind hand" (Benett, MS-Papers-0083-010A letter dated 24 April 1824). Likewise, her distance from the metropolis meant access to the latest research was 
problematic, she complained to Mantell that her local booksellers: "do not like the trouble of inquiring for periodical publications and as they get little by them they care not whether you have them or not" (Benett, MS-Papers-0083-010A letter dated 29 August 1816). Equally, if not more significant, therefore, was Benett's extensive network of geological correspondents, which included exchanges of both letters and fossils with many of the leading experts and institutions of the day, both in Britain and abroad. However, her gender prevented her from converting such informal exchanges into access to formal scientific networks, as women were only admitted to the Geological Society in 1919. As a result, she was symbolically relegated to the subaltern status of a mere collector by more formally legitimised geologists such as James Sowerby, who drew abundantly on Benett's fossils for his multi-part Mineral Conchology of Great Britain but failed to acknowledge her contribution in his publication, and William Fitton, who failed to acknowledge a loan of fossil specimens (Letter dated 12 October 1831 in Cleevely, Benett's correspondence with James Sowerby). Ironically, her home country proved more reticent in granting her access to loci of scientific authority than did geological institutions abroad, where she was presumed to be a man, doubtless due largely to her first name that was regularly confused with the better-known masculine Ethelred, as she tartly noted in a letter to Mantell: "you have lately taken to spelling my Christian name Ethelred, whereas it is Etheldred" (Benett, MS-Papers-0083-010A letter dated 4 November 1842, emphasis Benett's). She was granted an honorary doctorate of civil law from St Petersburg, for example, in recognition of a donation of fossils. While she was doubtless pleased to receive such an accolade, she nonetheless felt compelled to complain to her correspondent Samuel Woodward, a Norwich-based bank clerk and amateur geologist, that: "it is provoking that no-one will believe that a Lady could write such a trifling thing - in this Diploma I am called Dominum Etheldredum Benett \& Mr Lyell told me that he had been written to by foreigners to know if Miss Benett was not a gentleman... so you see that scientific people in general have a very low opinion of the abilities of my sex" (Burek 193, emphasis Benett's). Denied access to formal scientific recognition in the public sphere, she used her correspondence network to engage in geological debate and did not scruple to make the case for her own scientific authority through this informal channel, complaining in an 1822 letter to Greenough that "I have now a second instance of [Sowerby's] blundering [...] I proved the error to him by specimens, and he admitted it but never noticed it in a subsequent part of the work that I have seen, and which for his own credit for correctness he ought to have done" (Burek 192).

Benett's 1831 fossil catalogue provides further evidence of the complexity of her place within the networks of early-nineteenth-century British geology. Exploring its status as a publishing artefact reveals the strategies she used to negotiate her place in the construction of geological knowledge. Benett's earliest ventures into social authorship took the form of two contributions to the Geological Society - a stratigraphical section of Chicksgrove Quarry (1815) and her Sketches of Fossil Alcyonia from the Green Sand Formation at Warminster Common and the Immediate Vicinity of Warminster in Wiltshire (1816). Both were handwritten and hand-drawn, in keeping with the stance of informal knowledge exchange espoused in the Society's founding manifesto. However, by the mid-1810s, the Society had begun to establish mechanisms for attributing scientific legitimacy via peer review and publication in the Transactions of the Geological Society, first launched in 1811, thereby marginalising the model of social authorship that better suited Benett's geographical situation and 
gender. She began to think of publication in 1818, writing to Mantell that: "You will now I fear think me bold indeed when I tell you that since that time I have undertaken to attempt the Geology of Wiltshire decidedly for publication both as a separate thing and for the County History" (Benett, MS-Papers-0083-010A letter dated 23 March 1818). However, she discontinued work on the project when her brother decided to stand for parliament in 1819. Not until 1831 was her nine-page "Slight sketch of the geology of South Wilts" included in Sir Richard Colt Hoare's Modern History of South Wiltshire, printed in London for John Nichols and son, who specialised in antiquarian topics. Later that year, Benett had an amended version printed as the Catalogue of the Organic Remains of the County of Wiltshire, with the addition of a number of lithographic plates. The work was carried out by Joshua Lambert Vardy, a jobbing printer in Warminster whose output consisted largely of religious tracts and works of purely local interest; he also printed labels for Benett's fossil specimens (Spamer et al. 125). As was commonly the case for provincial printers, he also had a number of other professional activities, as a stamp agent, patent medicine seller, lottery and insurance agent, and inspector of corn returns.

The semiotics of the material publishing artefact play a key role in claims to scientific authority. The differences between the two versions of Benett's catalogue are thus highly instructive. Colt Hoare's prestigious, multi-volume publication was readily granted a place on the mainstream London publishing and bookselling circuit, where it stood alongside works of comparable scientific content to Benett's catalogue, such as Gideon Mantell's Descriptive Catalogue of the Objects of Geology, Natural History and Antiquity (Chiefly Discovered in Sussex) in the Museum, attached to the Sussex Scientific and Literary Institution at Brighton (1836). Benett's stand-alone catalogue, by contrast, was the work of a humble provincial printer with little in the way of scientific - or indeed publishing - credentials, and, being privately distributed, had no place at all on recognised bookselling circuits. Its print run is unknown, but presumably low: Benett's only other published work, a family history printed by Vardy in 1833, had a private print run of 100 copies (Wake unpaginated).

Benett's preface states that "when this catalogue was first thought of, my geological friends expressed a wish that it should be published separately; but considering it a thing of mere local interest, I have preferred printing a few copies only for the acceptance of my Friends" (Catalogue unpaginated). This prefatory statement located the catalogue in the private sphere in three ways: spatially, since self-publishing literally kept the resulting publication out of commercial premises; thematically, as "a thing of mere local interest"; and socially, since she explicitly stated her intention to withhold the work from the broader public sphere by limiting it to an informal social circle. This raises an intriguing question: as a woman, could Benett have published the work in a manner more open to scientific legitimisation, if her "geological friends" were inviting her to do so? There was one precedent in the field of geology: the Transactions of the Geological Society had published Maria Graham's description of the geological impact of a major earthquake she had witnessed in Chile, in its 1824 issue - though this was filtered through a suitably masculine contributor, taking the form of a letter to Henry Warburton (Thompson 332). Benett could potentially have accessed London publishers via Aylmer Bourke Lambert, whose own botanical research was published in the metropolis, and through her other contacts: she passed Gideon Mantell's paper on fossil Alcyonium to Sir Joseph Banks, ensuring its publication with the Linnean Society in 1815 (Benett, MSPapers-0083-010A letter dated 21 May 1815). A letter to Mantell reveals Benett did 
give some thought to publishing strategies: "I think you should advertise it [Mantell's Catalogue] in one London paper, but I should think without the list of subscribers, as I believe it is desirable to make advertisements in the London Papers as short as possible, I see that all the books published at Murray's are advertised in the Morning Herald which I therefore conclude to be the fashionable paper for advertising the best works" (Benett, MS-Papers-0083-010A letter dated 18 May 1821). However, despite stating her intention to seek publication in 1818, she appears to have made no attempt to place her project with publishers in the metropolis, although she visited the city regularly and indeed called on a London lithographer for the illustrations.

The work's privately printed status thus appears to echo the typically feminine modesty topos in her preface, maintaining the work firmly in the private sphere despite invitations to make it public. However, the work's status is more complex than might at first appear to be the case. While many scientific authors were doubtless keen to build and maintain contacts in the mainstream publishing network as a means of achieving visibility as a route to scientific legitimacy, it is clear that this was not Benett's case. The social authorship model she espoused was an "authorial act [...] characteristic of very different physical conditions of writing and reading as well as a different self-definition of authorship" that "encouraged participation in literary life of groups of people whom print technology effectively isolated and alienated" (Ezell 12). Private printing enabled Benett to participate in the publishing world on her own terms. By controlling the diffusion of her works to a carefully restricted sphere, she was seen to respect the norms of female propriety and thus avoided becoming embroiled in an unseemly public dispute over the scientific legitimacy of her work, as Maria Graham had been (Thompson, "Earthquakes and Petticoats"; "Only the Amblyrhynchus"'). Since a general commercial readership was not her goal, the success of her catalogue was not to be measured through sales, but rather in the access to loci of scientific authority it afforded her. Benett's claim to be writing for an intimate readership belies the fact that her select circle of friends included the leading geologists of the day: the catalogue is dedicated to George Bellas Greenough, by then vice-president of the Geological Society, and copies were sent to William Buckland, William Conybeare, William Fitton and Adam Sedgwick, among others. Thus, while the catalogue's print format and preface seem to restrict her contribution to the informal sphere, its pattern of distribution suggests a real ambition to contribute to formal geological debate. Unable to seek scientific legitimacy through the usual paths of institutional and / or trade publication open to her male counterparts, she made use of an alternative model of authorship more suited to her gender and geographical location. In her case, its mechanism of consecration was to prove just as effective as the public authorship model used by her male counterparts as, despite the lack of a public readership, she made her work available for judgement by her scientific peers.

One interesting aspect of Benett's catalogue, that plays a role in determining the extent of its implicit claim to scientific credibility, is the presence of a number of lithographic plates of fossils, absent from the earlier Colt Hoare version. Lithography was a relatively recent arrival in Britain: by the late 1820s, just twenty-eight lithographic printers were recorded in London, and the technique only spread to larger provincial towns in the mid-1830s. Interestingly, geology was one of the earliest fields of endeavour to adopt the technique, doubtless because geologists were in the forefront of efforts to locate suitable sources of lithographic stone in Britain to avoid significant import duties; William Smith and William Buckland both showed an interest in it, and John Phillips eventually set up his own lithographic press (Twyman, 
Breaking the Mould 21,31). Though its proximity to handwriting made it semiotically unsuitable for textual material that needed to look authoritative (Breaking the Mould 170), it was excellent for reproducing fine-grained detail in scientific illustration (Cleal et al. 42) and improved the presentation of non-linear textual material such as stratigraphical tables.

Benett's awareness of the semiotic significance of print is suggested by the changes she made to the layout of her material between the two versions of her catalogue to draw attention to the new content, including seventy-seven new species and one new genus (Pearce and Arnold 183). Her experiments with geological lithography as early as 1819 thus suggest her intention to make her catalogue a serious work of scientific communication, though she may also have been swayed by considerations of cost, lithography being twice as cheap as copper engraving (SheetsPyenson 28). Benett was well aware of her own shortcomings as an artist, writing to Mantell: "I must now refer to the very rough sketches that I have ventured to send you on the other half sheet of this paper, my Eye, totally unused to sketching, has not I fear kept up the just proportions" (Benett, MS-Papers-0083-010A letter dated 20 October 1815). The plates are a considerable improvement on Benett's own drawings and thus improve the work's scientific credentials (See Figures 1 and 2).

Fig. 1.

Etheldred Benett's drawing of Polypothecia dichotoma.

Reproduced by permission of the Alexander Turnbull Library, Te Puna Mātauranga o Aotearoa/National Library of New Zealand. 


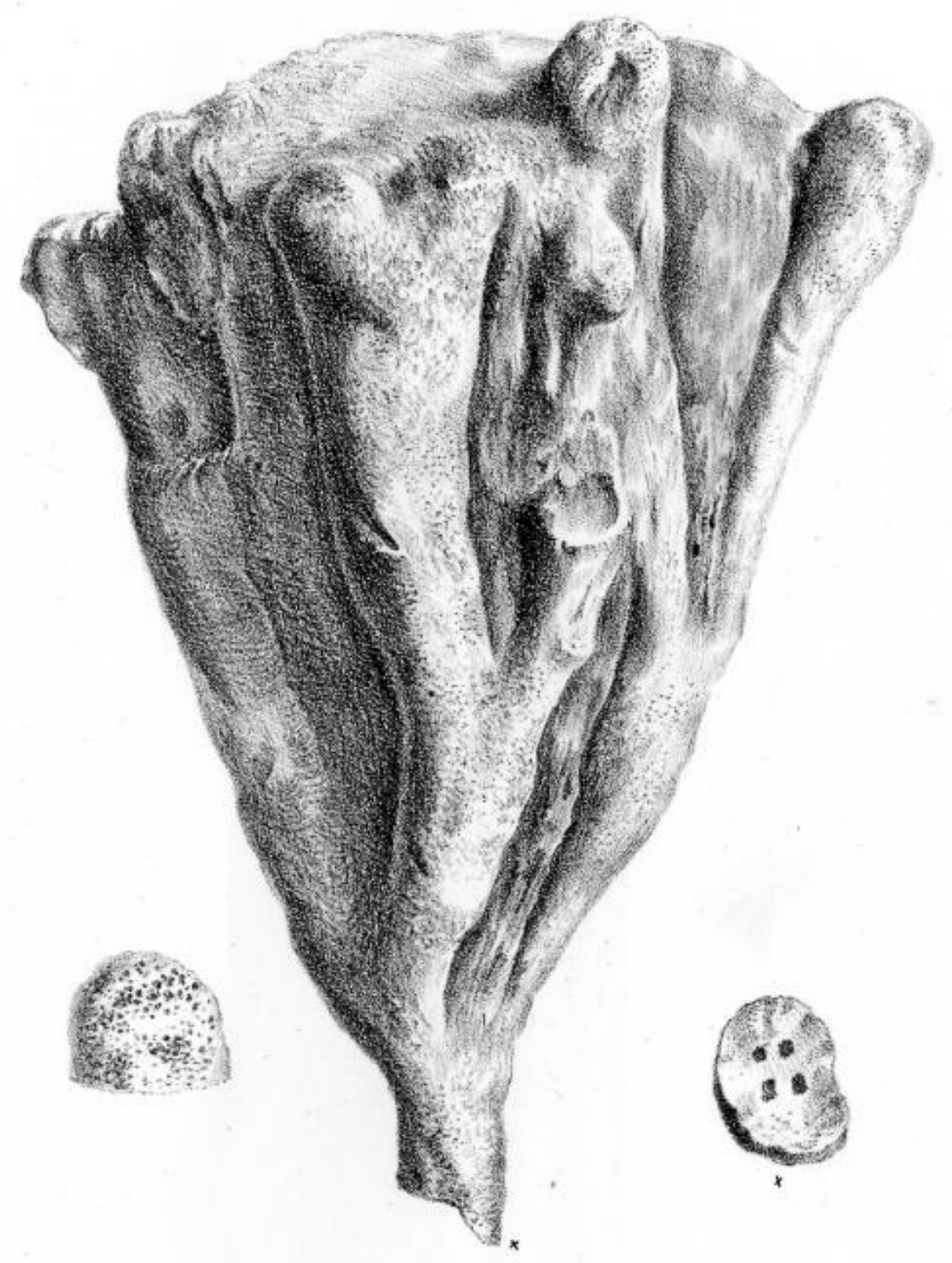

Polypotheoia dichotoma.

EDSmith del:

\section{Fig. 2.}

Lithographic plate of the same specimen by E.D. Smith in Etheldred Benett. A Catalogue of the Organic Remains of the County of Wiltshire. Warminster: J. L. Vardy, 1831. Unpaginated. Reproduced by permission of the British Geological Survey @ NERC.

The engravings, by E.D. Smith of Chelsea Common, were presumably commissioned during one of Benett's annual trips to London. Although a definitive identification is impossible at this remove, the artist is likely to be Edwin Dalton Smith, a relatively 
well-known botanical artist who was artist in residence at Kew Gardens and who, as a fellow of the Linnean Society, may have known Aylmer Bourke Lambert. ${ }^{2}$ Benett described her experience with the technique in a letter to Mantell:

With much pleasure I will give you all the information I have in my power respecting lithography, but you have seen all that I have done of it and I am stop'd for the present, I have no doubt however that it will answer for all the coarser fossils, particularly those of the sand, but I fear you will find that your beautiful chalk specimens require finer work and that it will still be necessary for Mrs Mantell to go on engraving them; you will perhaps be surprised to hear that I have had nothing to do with the stones, nor can I reverse a drawing without so much trouble as would make it useless to me; any drawing was made in the usual manner, but on paper prepared for the purpose and with a particular kind of ink. This drawing I sent to the person who takes off the impressions; by a chemical process he transmits the drawing to the stone and this reverses it, he then repairs any injury it may receive in the transmission as well as he can [...] those drawn on the stone when well done are much the clearest, but I have seen much better than mine done the same way, and it is I believe infinitely less trouble [...] I had twelve copies only of mine not wanting more of a thing done merely for trial [...] but I am told that from 50 to 60 impressions may usually be obtained [...] Mr Moser, lithographer, No. 2 or 3 of Grosvenor Street, Hunter Street, Brunswick Square, is I am told the best person to supply the materials and take off the impressions of lithographic drawings and him I employed, he usually prepares the drawing paper in half sheets at one shilling the half sheet but he does whole sheets at two shillings each if ordered which for my purpose answered better. (Benett, MS-Papers-0083010A letter dated 29 June 1819)

This makes Benett a very early adopter of the technique indeed: Twyman (Directory 4) notes that "the earliest reference to lithographers I have managed to trace in any directory appear in the Post Office London Directory for 1820"; these references include a Francis Moser who ran a press at his home at "4, Greenland-place, CromerStr. Brunswick-Square." Benett was well in advance of the Transactions of the Geological Society, which adopted lithography in 1824, following Charles Hullmandel's demonstration of the technique's value for the geology market in around 1820 (Rudwick, "The Emergence of a Visual Language for Geological Science" 156). As such, she was in fact at the forefront of a drive to create a "visual language of geology" which reflected the "growth of a self-conscious community of geological scientists" ("The Emergence of a Visual Language" 150-51). Benett's early uptake of lithography, her decision to use an established botanical artist, and her reorganisation of layouts between publications can all be read in terms of a desire to produce a work that shared, even adumbrated, the print characteristics of publications like the Transactions that represented the cutting edge of geological visual culture (see: Rudwick, "The Emergence of a Visual Language"). Her use of a male lithographer also represents an interesting reversal of the process by which illustration was deemed to be a way for women to participate in the sciences - a process used by male institutional gatekeepers to channel women's involvement into feminine accomplishments that could be carried out within the home (Shteir, "Elegant 
Recreations?" 241).

\section{Recovering Benett's scientific legacy}

Benett's work, like that of many other early female participants in the sciences, has been progressively rediscovered since the 1980s as part of the ongoing feminist challenge to dominant historiographies of science. Gender was, and remains, a significant frame in reading her work. An anonymous Warminster writer described her in 1872 as a "masculine and eccentric old subject" who generally wore "a drab coachman's sort of greatcoat" (Torrens et al. 64). More recently, she has been described as "magnanimous, meticulous and manly" (Burek 194). Given this gendered frame of reading, it is interesting to note that the status of her catalogue as a publishing artefact came to play a key role in determining her retrospective recognition by the scientific community in the late twentieth century.

The debate, sparked by the rediscovery in the 1980s of the bulk of her collection in the Academy of Natural Sciences in Philadelphia, turned on whether Benett's use of the nomenclature Drepanites for a new genus in her catalogue should take precedence over the subsequent unrelated use of the same term by Edmund Mojsisovics von Mojsvar, chief geologist at the Geological Institute at the University of Vienna, in 1893. ${ }^{3}$ Perhaps ironically, Benett had herself chosen Drepanites to avoid using a nomenclature already "preoccupied" by another genus, as she wrote to Samuel Woodward in 1831:

As to my genus Drepanites I am rather at a loss what to say about it, the late Mr. Parkinson examined the figure very minutely and said it was certainly quite a new thing and gave me the name of Pedum for it but that being preoccupied by a bivalve could not stand of course and I of course changed it. (qtd. in Pearce and Arnold 184)

The case turned on whether Benett's Catalogue was a publication according to the definition laid down by the International Commission on Zoological Nomenclature, which stipulated that publication meant that the work must be made available in "an edition containing simultaneously obtainable copies" produced using a method "that assures numerous identical copies" (Spamer et al. 131). Benett herself clearly held that the privately printed status of her work was no barrier to establishing scientific nomenclature, writing to Mantell that: "My Nerita Tisburiensis is named differently by Dr Fitton but my name being publish'd and his still in manuscript my name must stand Dr Sowerby says" (Benett, MS-Papers-0083-010A letter dated 20 June 1833). However, when the International Commission invited opinions from interested parties in 1990, Claud William Wright (1917-2010), a senior civil servant and leading amateur geologist, argued that Benett's use of Drepanites was taxonomically a nomen nudum (i.e. a designation that follows standard scientific taxonomy but fails to meet the requirement of being published with an adequate description) ("Comments" 18788, 218-19). He cited Benett's preface to make the case that since the catalogue was privately printed and distributed, it could not be said to be publicly available in the manner dictated by the International Commission for establishing precedence in matters of nomenclature. The ambiguous status of the Catalogue as a print artefact, resulting from Benett's adherence to gendered norms of participation in nineteenthcentury science, was thus to have a long shadow, as her decision to print privately with Joshua Lambert Vardy of Warminster nearly determined her ongoing exclusion 
from official scientific nomenclature late in the twentieth century. Ironically, as Benett herself made clear in her preface, she only came up with new names herself due to the failure of her male correspondents to fulfil their promises to her, itself a sign of the subaltern status afforded to her as a participant in the construction of geological knowledge:

If it should be objected to my new names in the genus Polypothecia, that they are all derived from external form; I beg to state, that three scientific gentlemen undertook, at different times, to describe and name this class of fossils, and to each I offered all the assistance which my very large collection afforded; that all have disappointed me; and that having waited fifteen years, [...] I have done the best I could. (Catalogue unpaginated)

Wright's argument was ultimately rejected by the International Commission's secretary P. K. Tubbs on the grounds that "pragmatic considerations should outweigh Miss Benett's statement of her modest plans for the distribution of her catalogue" ("Comments" 188). These pragmatic considerations were largely that Benett's work, while ostensibly seeking to remain within the private, informal sphere, had in fact circulated far beyond it in terms of reception. Tubbs argued that "despite Benett's evident pre-printing intention or expectation, it would appear that more than a 'few' copies of the catalogue may have been circulated" ("Comments" 188). Indeed, while Benett could be claiming to remain within the private sphere of her informal network when sending copies of her work to her "geological friends", she also stepped into the public sphere by depositing copies with a formal network of scientific institutions including the Woodwardian Museum in Cambridge, the Bristol Institution, the Société Géologique in Paris (who recorded the work as a donation by "M. Ethelred Bennett" $[s i c]$ ), and the British Museum, thereby fulfilling its legal deposit requirement ("Comments" 188, 219). This suggests a strategy on Benett's part of exploiting the overlap in membership between the two geological networks: while her gender meant she could only play an active role in the informal network, she could certainly exploit her place in it to bring her work to the attention of formal geological institutions. If the Catalogue's pattern of distribution was indeed the result of a deliberate strategy to shape formal geological debate from within an informal network, it proved successful: several of her nomenclatures became standard in nineteenth-century geological literature. As a result, the International Commission ultimately considered that Benett's stated espousal of the modesty topos was outweighed by the work's distribution and reception. Her contribution to early English geology was accordingly formally acknowledged by the International Commission, who placed her Catalogue on the official list of works approved as available for zoological nomenclature, thereby granting her a degree of the scientific legitimacy that her gender-based restriction to informal knowledge networks had largely denied her in her own lifetime.

Where the socially authored manuscript works studied by Margaret Ezell overtly signalled their difference from published works through the semiotics of handwriting vs. print, such visual differentiation was far less flagrant in the case of Benett's privately printed Catalogue, which mimicked - and even anticipated - the semiotics of mainstream geological publications. This ambiguity is what enabled her to play astutely with the expectation that women would limit their participation in the literary field to social authorship, claiming limited circulation for her work and thereby escaping potential censure for overstepping her gender boundaries, while in 
fact ensuring a significant, albeit numerically limited, pattern of distribution that brought her Catalogue to the attention of the key instances of legitimisation in the field of geology. 


\section{Notes}

1. Etheldred Benett, letter to James Sowerby, 27 February 1814. Sowerby correspondence transcribed by R.J. Cleevely. Eyles Collection, Special Collections, Bristol University Library.

2. My thanks to Alison E. Martin for helping to identify the artist.

3. This section draws largely on Spamer et al. for an account of the controversy. 


\section{Works Cited}

Allen, David E. "The Women Members of the Botanical Society of London, 183656." British Journal for the History of Science 13 (1980): 240-54.

Benett, Etheldred. Correspondence with Gideon Mantell. MS-Papers-0083-010A. Alexander Turnbull Library, National Library of New Zealand.

Benett, Etheldred. A Catalogue of the Organic Remains of the County of Wiltshire. Warminster: J.L. Vardy, 1831.

Buckland, Adelene. Novel Science: Fiction and the Invention of Nineteenth-Century Geology. Chicago: Chicago UP, 2013.

Bulletin de la Société Géologique de France 2 (1832).

Burek, Cynthia. "The First Lady Geologist." Geology Today 17.5 (2001): 192-95.

Cleal, Christopher, Margaret Lazarus and Annette Townsend. "Illustrations and Illustrators during the Golden Age of Palaeobotany: 1800-1840." History of Palaeobotany: Selected Essays. Eds. A. J. Bowden, C. V. Burek and R. Wilding. London: Geological Society, 2005. 41-61.

Cleevely, R. "Miss Etheldred Benett (1775-1845): A Preliminary Note on her Correspondence." Wiltshire Archaeological and Natural History Magazine 97 (2004): 25-34.

---. Transcription of Etheldred Benett's correspondence with James Sowerby. Eyles Collection, Special Collections, Bristol University Library.

Colt Hoare, Richard. Modern History of South Wiltshire. Vol. 3. London: John Nichols and Sons, 1831.

"Comments on the Proposed Conservation of Drepanites Mojsiskovics, 1893 and Hyphoplites Spath 1922 (Mollusca, Cephalopoda)." Bulletin of Zoological Nomenclature 47.3 (1990): 187-88, 218-19.

Dawson, Gowan. "Literary Megatheriums and Loose Baggy Monsters: Paleontology and the Victorian Novel." Victorian Studies 53. 2 (Winter 2011): 203-30.

Delair, Justin. "Pioneer Geologists of the Salisbury Area." Wiltshire Archaeological and Natural History Magazine 87 (1994): 127-41.

Ezell, Margaret. Social Authorship and the Advent of Print. Baltimore: Johns Hopkins UP, 1999.

Haycock, Lorna. "'In the newest manner': Social life in late Georgian Devizes." Wiltshire Archaeological and Natural History Magazine 97 (2004): 1-14.

Heringman, Noah. Romantic Rocks, Aesthetic Geology. Ithaca: Cornell UP, 2003. "History of the Geological Society." Web. 14 November 2014.

Knell, Simon. The Culture of English Geology, 1815-1851. Aldershot: Ashgate, 2000.

Lewis, Cherry and Simon Knell, eds. The Making of the Geological Society of London. London: Geological Society, 2008.

"List of Fellows." Transactions of the Linnean Society of London 17 (1835). 5-13.

Mantell, Gideon. Descriptive Catalogue of the Objects of Geology, Natural History and Antiquity (Chiefly Discovered in Sussex) in the Museum, attached to the Sussex Scientific and Literary Institution at Brighton. London: Relfe and Fletcher, 1836.

Meadows, Arthur. The Development of Science Publishing in Europe. Amsterdam: Elsevier, 1980.

Murchison, Roderick. "Address to the Geological Society, Delivered on the Evening of the 17th of February 1832." Proceedings of the Geological Society of London 25 (1832): 362-86. 
Nash, Sarah. "The Collections and Life History of Etheldred Benett (1776-1845)." Wiltshire Archaeological and Natural History Magazine 83 (1990): 163-69.

O'Connor, J. and A. Meadows. "Specialization and Professionalization in British Geology." Social Studies of Science 6 (1976): 77-89.

O'Connor, Ralph. The Earth on Show. Fossils and the Poetics of Popular Science, 1802-1856. Chicago: Chicago UP, 2007.

Pearce, Susan, and Kenneth Arnold, eds. The Collector's Voice. Vol. 2: Early Voices. Aldershot: Ashgate, 2000.

Porter, Roy. "Gentlemen and Geology: The Emergence of a Scientific Career, 16601920." The Historical Journal 21.4 (1978): 809-36.

Rudwick, Martin. "The Emergence of a Visual Language for Geological Science, 1760-1840." History of Science 14 (1976): 148-95.

---. The Great Devonian Conspiracy: The Shaping of Scientific Knowledge among Gentlemanly Specialists. Chicago: Chicago UP, 1985.

Secord, Anne. "Artisan Botany." Cultures of Natural History. Ed. N. Jardine, J. Secord and E. Spary. Cambridge: Cambridge UP, 1996. 378-93.

Sheets-Pyenson, Susan. "A Measure of Success: The Publication of Natural History Journalism in Early Victorian Britain.” Publishing History 9 (1981): 21-36.

Shteir, Ann B. "Elegant Recreations? Configuring Science Writing for Women." Victorian Science in Context. Ed. Bernard Lightman. Chicago: Chicago UP, 1997. 236-55.

---. "Finding Phebe: A Literary History of Women's Science Writing." Women and Literary History: 'For There She Was'. Ed. K. Binhammer and J. Wood.

Newark: Delaware UP, 2003. 152-66.

Spamer, Earle, Arthur Bogan and Hugh Torrens. "Recovery of the Etheldred Benett Collection of Fossils mostly from Jurassic-Cretaceous Strata of Wiltshire, England, Analysis of the Taxonomic Nomenclature of Benett (1831), and Notes and Figures of Type Specimens Contained in the Collection."

Proceedings of the Academy of Natural Sciences of Philadelphia 141 (1989): 115-80.

Talairach-Vielmas, Laurence. "Shaping the Beast: The Nineteenth-Century Poetics of Palaeontology." European Journal for English Studies 17.3 (2013): 269-82.

Thompson, Carl. "Earthquakes and Petticoats: Maria Graham, Geology, and Early Nineteenth-Century 'Polite' Science.” Journal of Victorian Culture 17.3 (2012): 329-46.

---. “'Only the Amblyrhynchus': Maria Graham's Scientific Editing of Voyage of HMS Blonde (1826/27)." Journal of Literature and Science 8.1 (2015): 48-68.

Topham, Jonathan. "Scientific Publishing and the Reading of Science in NineteenthCentury Britain: a Historiographical Survey and Guide to Sources." Studies in History and Philosophy of Science 31A.4 (2000): 559-612.

Torrens, Hugh, et al. "Etheldred Benett of Wiltshire, England, the First Lady Geologist: Her Fossil Collection in the Academy of Natural Sciences of Philadelphia, and the Rediscovery of 'Lost' Specimens of Jurassic Trigoniidae (Mollusca: Bivalvia) with Their Soft Anatomy Preserved." Proceedings of the Academy of Natural Sciences of Philadelphia 150 (2000): 59-123.

Turner, S., C. Burek and R.T. Moody. "Forgotten Women in an Extinct Saurian (Man's) World." Dinosaurs and Other Extinct Saurians: A Historical Perspective. Eds. R.T. Moody, et al. London: The Geological Society, 2010. 111-53. 
Twyman, Michael. Directory of London Lithographic Printers, 1800-1850. London: Printing Historical Society, 1976.

---. Breaking the Mould: The First Hundred Years of Lithography. London: British Library, 2000.

Wake, William. A Brief Enquiry into the Antiquity, Honour and Estate of the Name and Family of Wake. Ed. Etheldred Benett. Warminster: J.L. Vardy, 1833.

Woodward, Horace. "Geology in the Field and in the Study." Proceedings of the Geologists' Association 13 (1895): 247-73.

Zimmerman, Virginia. Excavating Victorians. Albany: SUNY Press, 2008. 